\title{
THE EFFECT OF FOLIAR FERTILIZATION ON THE YIELD AND QUALITY PARAMETERS OF MAIZE GRAIN
}

\author{
Péter Jakab, Gábor Zoltán, DÁvid Festö, Levente KoMAReK \\ University of Szeged, Faculty of Agriculture \\ Institute of Plant Sciences and Environmental Protection \\ Institute of Economy and Rural Development \\ Andrássy út 15, 6800 Hódmezővásárhely, Hungary \\ jakabpeter@mgk.u-szeged.hu
}

\begin{abstract}
In our small plot experiment, we examined the effect foliar fertilization on the yield and quality parameters of maize grain in 2016. The experiment was set in three replications, random blocks on the area of Tangazdaság Ltd. in Hódmezővásárhely. The soil of the experiment was meadow chernozem. We sprayed out three different foliar fertilizer products individually and combined with each other as well, so there were six treatments and the control to be examined. The year 2016 was favourable for maize production. In 2016 the amount of precipitation in the vegetative period of corn was higher by $23.7 \mathrm{~mm}$ than the average. We processed the obtained data by single factor variant analysis. We obtained $11.37 \mathrm{t} / \mathrm{ha}$ in control treatment, and with the foliar fertilization the yield ranged between 11.61-12.86 t/ha. The foliar fertilization products increased the yield of corn, but this difference was not significant. By the application of foliar fertilization, the qualty parameters of maize grain improved in many cases. Our scientific results proved, that foliar fertilization had god effect on the yield and quality parameters of maize.
\end{abstract}

Keywords: maize, foliar fertilization, yield, crude protein content, starch content

\section{INTRODUCTION}

The genetical productivity of the newest maize hybrids is continuously growing. In order that the potential of hybrids productive capacity can be utilized as much as possible, the harmony of the agro-technical factors is necessary (KOVÁCS AND SÁRVÁRI, 2016).

The low average yield in maize production can be due to the fall-back of chemical fertilization; this is why the use of fertilizers must be increased in order to reach higher and more consistent amounts of crop (KOMAREK, 2007).

In practice, foliar fertilisers are able to meet only a few percent of the main macroelement demands of plants. Foliar fertilisation cannot provide nutrient uptake through the soil, just supplements it. The foliar fertiliser can get directly to the place of use, the leaf cells and can act immediately without the mediation of the soil. Nutrient uptake can be sustained even in drought, with little water. Under ideal conditions, the nutrient utilisation might reach 100\% (KÁDÁR, 2002).

According to KÁDÁR (2008) the future spread of foliar fertilisation must be grounded by comprehensive experimental research. Accurate, repeated small plot trials are necessary to clarify the factors influencing the effectiveness of foliar fertilizers and recommendations must be developed for consultation.

Nowodays, in order to achieve high yields, cultivated plants cannot always get enough microelements from the soil, therefore the importance of foliar fertilization increased. The timing is decisive for rapid and effective intervention to prevent yield loss or deterioration, and we can achieve yield increase and quality improvement as well. With the application of foliar fertilization, we can increase the resistance of corn against the ecological stress factors, diseases and pests as well (HOFFMANN ET AL., 2004). 
Foliar fertilization had good effect in maize production on meadow chernozem soil, wich. contains a lot of phosphorus and a few amount of $\mathrm{Zn}$. The foliar fertilization products can decrease the yield fluctuation and increase the yield amount. (JAKAB ET AL., 2014a; JAKAB ET AL., 2014b; JAKAB ET AL., 2016a; JAKAB ET AL., 2016b; JAKAB ET AL., 2016c; ZOLTÁN AND JAKAB, 2016; JAKAB AND KOMAREK, 2017).

\section{MATERIAL AND METHOD}

\section{Soil properties of the experimental field}

The research work has been carried out at the SZTE Tangazdaság Ltd. in Hódmezővásárhely. The soil was meadow chernozem, the reaction of which was nearly neutral $\left(\mathrm{pH}_{\mathrm{KCL}}\right.$ 7.17). Before setting the experiment, the soil analysis data showed that it had good nitrogen, and very good phosphor and potassium contents. The $\mathrm{Zn}$ content was low (Table 1).

Table 1. Main properties of the experimental field area

\begin{tabular}{|c|c|c|c|c|c|}
\hline $\begin{array}{c}\mathbf{p H} \\
(\mathbf{K C L})\end{array}$ & $\begin{array}{c}\mathbf{P}_{2} \mathbf{O}_{5} \\
(\mathbf{m g} / \mathbf{k g})\end{array}$ & $\begin{array}{c}\mathbf{K}_{2} \mathbf{O} \\
(\mathbf{m g} / \mathbf{k g})\end{array}$ & $\begin{array}{c}\text { Humus } \\
\mathbf{( \% )}\end{array}$ & $\begin{array}{c}\text { Soil plasticity } \\
\text { value (KA) }\end{array}$ & $\begin{array}{c}\mathbf{Z n} \\
(\mathbf{m g} / \mathbf{k g})\end{array}$ \\
\hline 7.17 & 336 & 620 & 3.39 & 48 & 1.76 \\
\hline
\end{tabular}

Weather in the experimental years

The year 2016 was favourable for corn production. In 2016 the amount of precipitation in the vegetative period of corn was higher by $23.7 \mathrm{~mm}$ than the average (Table 2). The average temperature showed a positive deviation compared to the average of several years. The positive deviation of average temperature together with deficient precipitation had a positive effect on the development of corn, which resulted high yields.

Table 2. The amount of rainfall in the vegetative period of maize in 2016

\begin{tabular}{|l||c||c||c||}
\hline Month & $\begin{array}{c}\text { Rainfall } \\
(\mathbf{m m})\end{array}$ & $\begin{array}{c}\text { 50 years } \\
\text { average rainfall } \\
(\mathbf{m m})\end{array}$ & $\begin{array}{c}\text { Difference } \\
(\mathbf{m m})\end{array}$ \\
\hline \hline April & 19.4 & 39.9 & -20.5 \\
\hline \hline May & 38.8 & 58 & -19.2 \\
\hline June & 86.0 & 75.3 & 10.7 \\
\hline July & 106 & 58.7 & 47.3 \\
\hline August & 47.6 & 48.7 & -1.1 \\
\hline September & 47.2 & 40.7 & 6.5 \\
\hline $\begin{array}{l}\text { Total amount of rainfall } \\
\text { (mm) }\end{array}$ & $\mathbf{3 4 5 . 0}$ & $\mathbf{3 2 1 . 3}$ & $\mathbf{2 3 . 7}$ \\
\hline
\end{tabular}

\section{Main features of the agro-technology applied}

The small plot experiment was set in three replications, organised as a random block in 2016. The fore-crop was winter wheat. Fall tillage involved deep ploughing at $30 \mathrm{~cm}$ depth in the experimental year. The sowing date was on 14 th of April. Plant density was 70.000/ha. The examined hybrid was Limanova (FAO 370). We applied three products individually and combined with each other as well, so there were six treatments and the control plot. The products were the followings: Algafix, Amalgerol and Fitohorm Turbo 
$\mathrm{Zn}$. The foliar fertilization was applied once in 6-7 leaves stage of plants. We harvested the plots by hand. We processed the obtained data by single factor variant analysis.

\section{RESULTS}

Due to the favourable ecological conditions the yield of the control plot was $11.37 \mathrm{t} / \mathrm{ha}$. With the application foliar fertilization the yield ranged between 11.61-12.86 t/ha. The foliar fertilization treatments increased the maize yield compared to the control, but it was not significant. We obtained the highest yield in the Amalgerol treatment (12.86 t/ha). We got high yield in Algafix + Amalgerol (12.34 t/ha) and Algafix + Fitohorm Turbo Zn treatment (Figure 1).

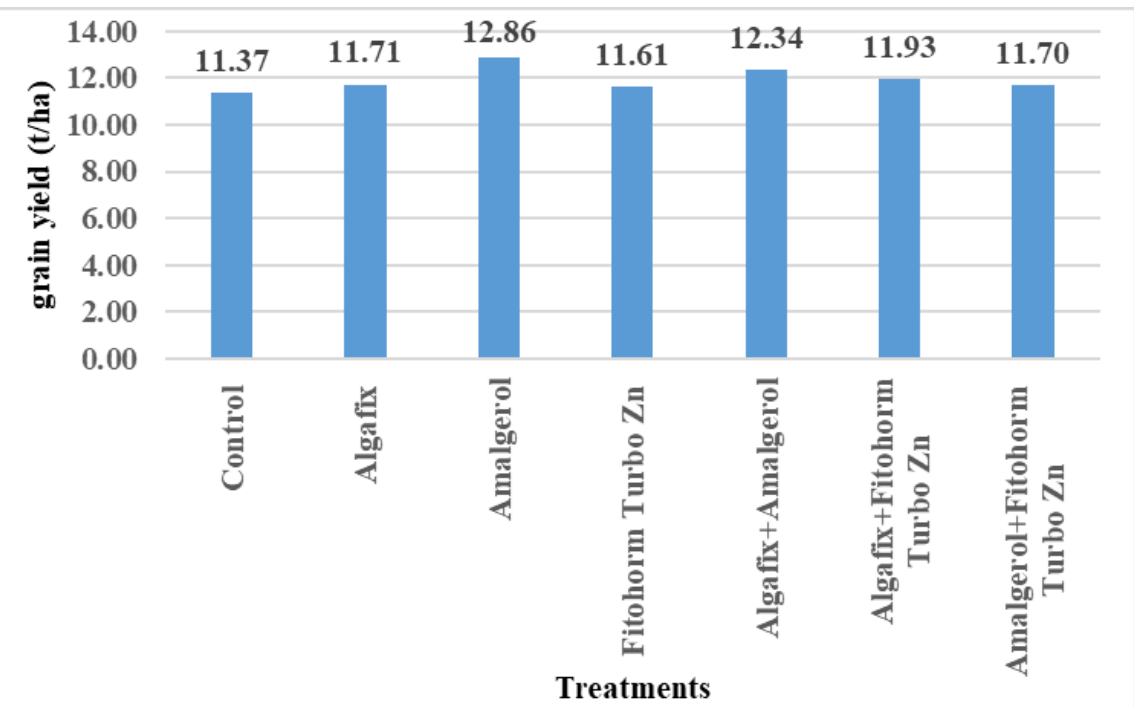

Figure 1. The yield of maize in control and different foliar fertilization treatment

We examined the effect of foliar fertilization on the main quality parameters (dry matter content, crude protein content, starch content) of maize. The dry matter content was 86.62 $\%$ in control treatment. Under the influence of foliar fertilizer treatments the dry matter content ranged between $86.37-87.25 \%$. Several treatments increased this parameter, but the change was not significant (Figure 2).

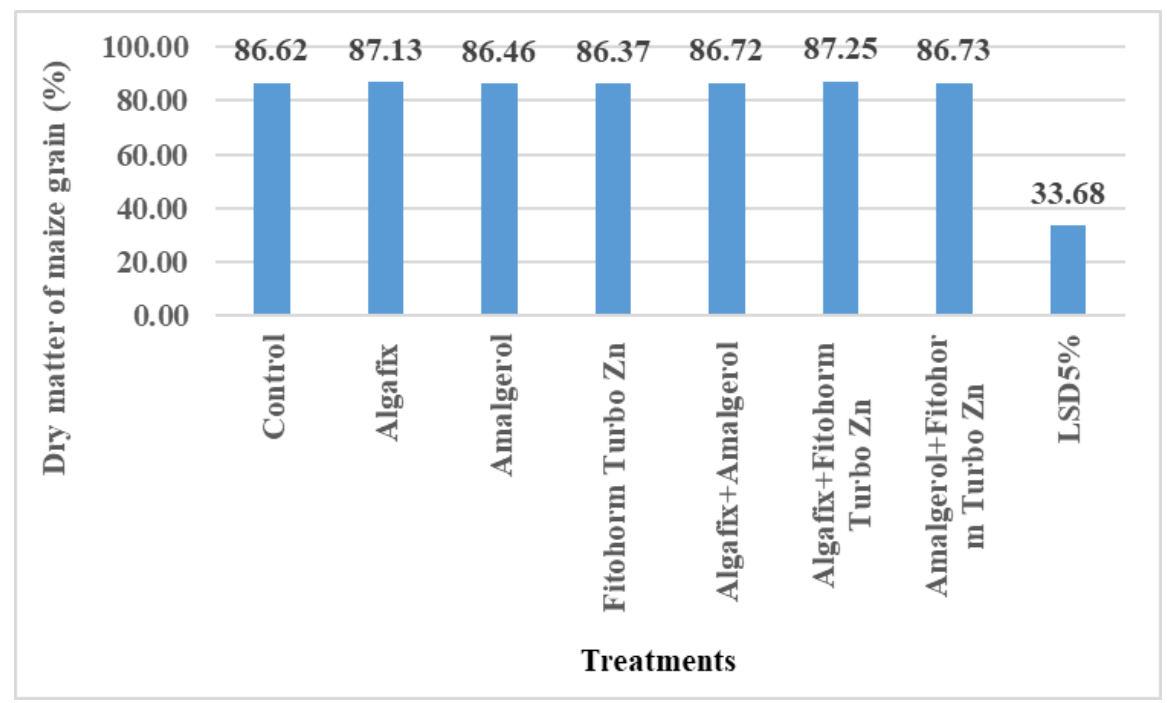

Figure 2. The effect of fertilizer treatments on the dry matter content of maize grain 
The value of crude protein $(77.95 \mathrm{~g} / \mathrm{kg})$ was the lowest in control treatment. In treated parcels we measured higher values $(77.36-78.88 \mathrm{~g} / \mathrm{kg}$ ), but the difference wasn't significant between control and treated results. The highest value we got in Algafix + Amalgerol treatment $(78.88 \mathrm{~g} / \mathrm{kg})$ (Figure 3).

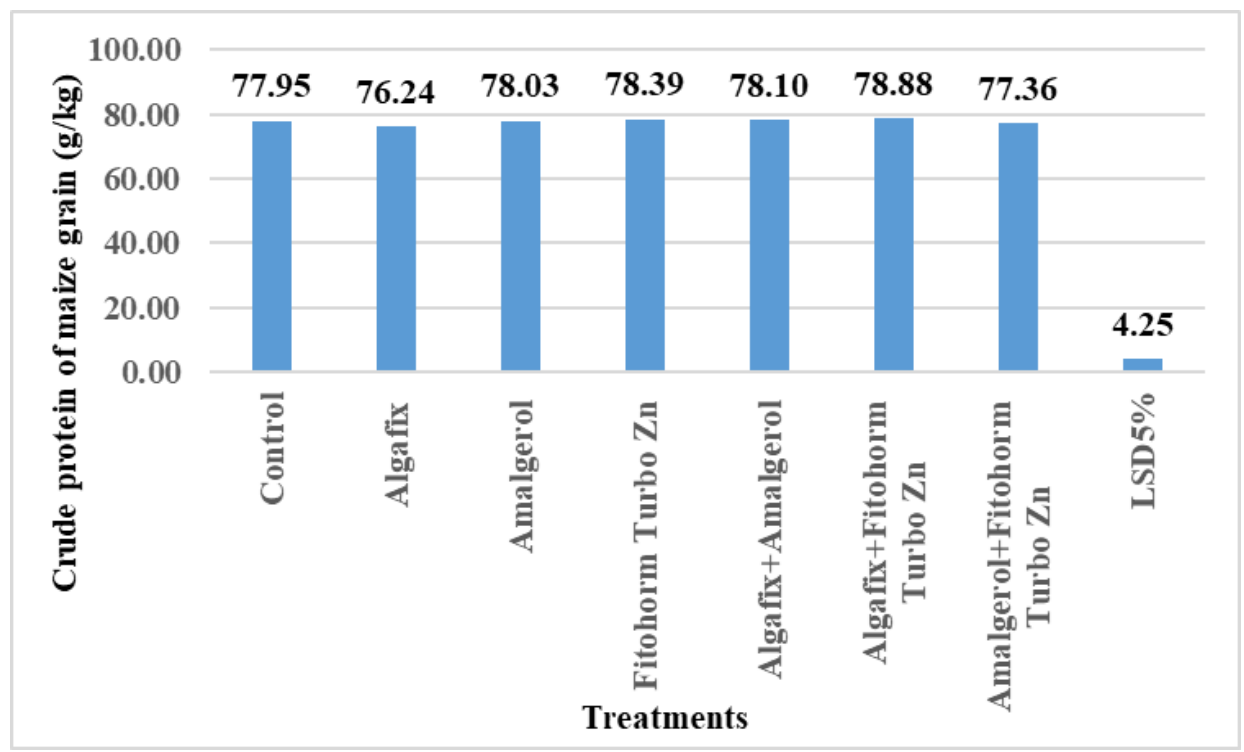

Figure 3. The effect of fertilizer treatments on the crude protein content of maize grain

The starch content of control treatment was $644.13 \mathrm{~g} / \mathrm{kg}$. We measured the highest value $(655.03 \mathrm{~g} / \mathrm{kg})$ in Amalgerol treatment. In Algafix + Amalgerol and Amalgerol + Fitohorm Turbo $\mathrm{Zn}$ treatments we measured significantly lower values $(626.0 \mathrm{~g} / \mathrm{kg})$ compared the control treatment (Figure 4).

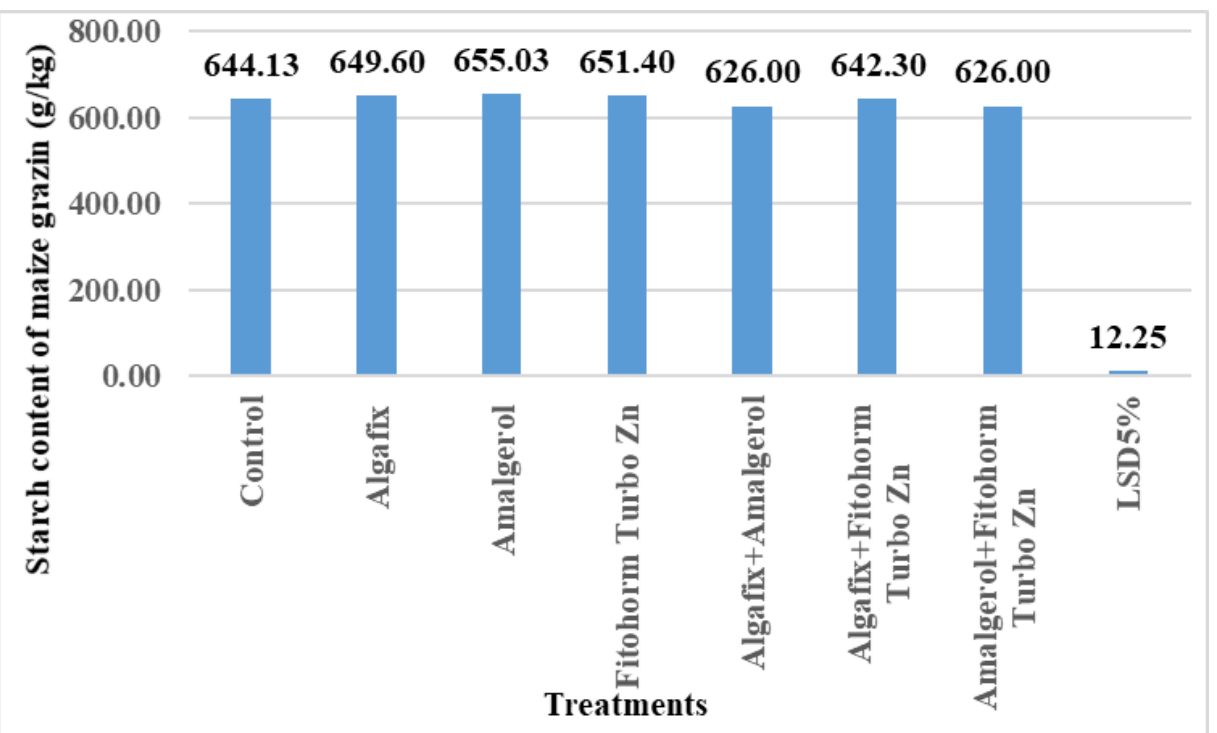

Figure 4. The effect of fertilizer treatments on the starch content of maize grain

\section{CONCLUSIONS}

The year 2016 was favourable for maize production therefore we obtained relatively high yield $(11.37 \mathrm{t} / \mathrm{ha})$ in non treated parcells. Under the influence the foliar fertilization the 
yield increased. In treated plots the yield ranged between 11.61-12.86 t/ha. The yield increasement compared the control was not significant. We examined the effect of foliar fertilizer treatment on the main quality parameters of maize grain. The foliar fertilizer products had good effect on the examined quality parameters, because in many cases improved the examined parameters. Our scientific results proved, that the foliar fertilization had favourable effect on the yield and quality parameters of maize, therefore it will be higher importance in the future in maize production.

\section{REFERENCES}

Hoffmann R.-VARGA Cs.-KARIKA A. (2014): Levéltrágyázás a gyakorlatban. Agrárium. 24(8): 69-72.

JAKAB P., KOMAREK L. (2017): The effect of foliar application on different fertilizers on technological and economical parameters of maize. Infrastructure and Ecology of Rural Areas, Krakow, (in. presss)

JAKAB P., SÜLi Á., NAGY P., KRISTÓ I. (2014a): The effect of foliar fertilization on the yield, chemical composition and nutrient value of maize. Lucrari Stiincifice Management Agricol 16(1): 202-205.

JAKAB P., NAGY P., KRISTÓ I. (2014b): Environmentally friendly nutrient supply of maize. Review on Agriculture and Rural Development 3(1): 320-323.

JAKAB P., ZOLTÁN G., KOMAREK L. (2016): The effect of foliar fertilization on the yield and generative factors of maize. Review on Agriculture and Rural Development 5(1-2): 158-161.

KÁDÁR I. (2002): Levéltrágyázás jelentősége és szerepe a növénytáplálásban. Az elméleti alapok összefoglalása. Gyakorlati Agrofórum 12: 7-10.

KÁDÁR I. (2008): A levéltrágyázás jelentősége és szerepe a növénytáplálásban. Acta Agronomica Óváriensis 50(1): 19-27.

KomAReK L. (2007): A Dél-Alföldi Régió súlyának, szerepének alakulása a hazai agrártermelésben. COMITATUS: ÖNKORMÁNYZATI SZEMLE 17(9) 52-64.

KOVÁCs P., SÁRVÁRI M. (2016): The effect of some agrotechnical factors on the yield of maize hybrids with different genetic base. Növénytermelés 65. (Supplement): 103-106.

JakAb P., Peter SzucSne J., SÜLi Á., Benk Á. (2016b): Study of foliar fertilization on the yield, chemical composition and nutrient value of corn. Lucrari tiintifice Management Agricol 18(1): 123-126.

JAKAB P., KOMAREK L., ZOLTÁN G. (2016c): The study of foliar fertilization in maize production, In: Futó Z. (szerk.): Kihívások a mai modern mezőgazdaságban. Magyar Tudomány Napja Konferencia Kiadványa, Szent István Egyetemi Kiadó, Gödöllő pp. 197202.

ZOLTÁN G., JAKAB P. (2016): Lombtrágya készítmények hatása a kukorica termésére és beltartalmára. In: Szalka É., Bali Papp Á. (szerk.): XXXVI. Óvári Tudományos Nap: Hagyomány és innováció az agrár- és élelmiszergazdaságban II. 335 p. Konferencia helye, ideje: Mosonmagyaróvár, Magyarország, 2016.11.10 Mosonmagyaróvár: Széchenyi István Egyetem Mezőgazdaság- és Élelmiszertudományi Kar, 2016. pp. 246-251. (ISBN 978-6155391-79-8) 